\title{
Cytotoxic and Antioxidant Activities of Selected South African Medicinal Plants
}

\author{
G Ayeni ${ }^{1}{ }^{1 *}$, OJ Pooe $^{1}$, M Singh $^{1}$, N Nundkumar ${ }^{1}$, MBC Simelane $^{2}$
}

G Ayeni ${ }^{1, *}$, OJ Pooe ${ }^{1}$, M Singh ${ }^{1}$, N Nundkumar ${ }^{1}, \mathrm{MBC}$ Simelane ${ }^{2}$

'Discipline of Biochemistry, School of Life Science, University of KwaZulu-Natal, Durban, SOUTH AFRICA.

${ }^{2}$ Department of Biochemistry, University of Johannesburg, Auckland Park, SOUTH AFRICA.

\section{Correspondence}

Gideon Ayeni

Discipline of Biochemistry, School of Life Science, University of KwaZulu-Natal,

Durban, SOUTH AFRICA.

Phone no: +27718667710; +234-

7068317885

E-mail: gideon4.ayeni@gmail.com

History

- Submission Date: 28-05-2019;

- Review completed: 11-06-2019;

- Accepted Date: 10-07-2019.

DOI : 10.5530/pj.2019.11.234

Article Available online

http://www.phcogj.com/v11/i6s

Copyright

(C) 2019 Phcogj.Com. This is an openaccess article distributed under the terms of the Creative Commons Attribution 4.0 International license.

\begin{abstract}
Introduction: Indigenous plants are known to play a pivotal role in the well-being of Africa's native societies. These plants are believed to be endowed with healing effects against various ailments rooting from oxidative stress. However, most of these plants including Ziziphus mucronata, Warburgia salutaris and Eucomis autumnalis lack scientific reports validating their medicinal properties. Thus, the current study, aimed to investigate the cytotoxic and antioxidant activities of selected South African medicinal plants. Methods: Scavenging activity of the extracts were evaluated on 2,2-diphenyl-1-picrylhydrazyl (DPPH), superoxide anion $\left(\mathrm{O}_{2}^{-}\right)$nitric oxide (NO-), hydroxyl anion (-OH) radicals and lipid peroxide (LP) values at varying concentration (20-100 $\mu \mathrm{g} / \mathrm{mL})$. Cytotoxic evaluation using 3-(4,5-dimethylthiazol-2-yl)-2,5-diphenyl tetrazolium bromide (MTT) was conducted on HEK293 cells. Reducing power and metal chelating ability of the extracts were assessed. In the same vein, protective index of DNA plasmid (pET151/D TOPO plasmid) induced free radical by incubating with Fenton's reagents were tested, in vitro. Reducing and metal chelating ability of the extracts were evaluated in this study. Results: The crude extracts displayed radical scavenging activity and limit peroxidation process. The extracts showed potent ferric reducing power and chelating effects. Cytotoxic effects of the extracts analyzed using the MTT assay displayed low toxicity levels. Furthermore, the extracts were able to protect pET151/D-TOPO plasmid DNA nicking induced by hydroxyl radicals in a Fenton's reaction mixture. Conclusion: It is evident in this study that the plant extracts are potential antioxidant therapeutics and justify inclusion of indigenous herbs as a complementary agents in the treatment regimen.
\end{abstract}

Key Words: Antioxidants, DNA, Eucomis autumnalis, Warburgia salutaris.

\section{INTRODUCTION}

Empirical usage of medicinal plants to treat diverse ailments and systematic investigation of their acclaimed properties, constitute the main focus of the current research trend in the main time. ${ }^{1,2}$ Over the past decades, a number of medicinal plants have been at the epicenter of drug discovery. ${ }^{3-5}$ This is due to their ability to protect sensitive and crucial organs that are prone to oxidative damaged initiated by the complex of reactive radical molecules generated in the biological system. ${ }^{5,6}$ The generation of these reactive oxygen species (ROS) is a well-known aerobic process, crucial for maintaining normal cellular functions such as signal transduction. ${ }^{7}$ Evaluation of ROS is based on the extent of oxidative challenges to macromolecular blocks; DNA, proteins, lipid and are thought to be major factor responsible for various pathophysiological derangements that are experiencing in ageing and various oxidatively induced diseases. ${ }^{8-10}$

Administration of both synthetic and natural antioxidant molecules have been shown to prevent the advancement of free radicals. ${ }^{11}$ Thus, the inhibition of radical species by natural molecular derivative have been a motivation towards progressive and systematic search for agents among native herbs that can inhibit toxic onslaught imposed by free radicals and with therapeutic ability to repair damaged done to the liver and other tissues. The search for such plants among the native herbs is urgently called for and as such worthy of empirical investigation. ${ }^{12}$ Free radical inhibitory effects with potent regenerative properties of good number of medicinal plants have been tested for and there were laudable empirical findings. Significant amounts of these plants' constituents limit and facilitate the regeneration of natural healing process of damaged liver, without eliciting toxicity on the experimental subjects model employed in the course of the investigation. ${ }^{2,13-17}$ Plant extract and their derivatives are currently in short supply due to high demand especially on their usage as alternative source of primary health care in developing world, owing to the low cost, availability and safety interms of treatment and management of liver disorders. ${ }^{18}$

Eucomis autumnalis (Mill) (Hyacinthaceae) Chitt is found distributed around southeastern-southern African Sub-region. ${ }^{19}$ The specie has been long time employed locally in the treatment of varieties of ailments and as well as facilitating child birth within the Province of Kwazulu-Natal, South African..$^{14,20}$ Antimicrobial and anti-inflammatory activity of the extract fractions was earlier investigated in vitro. The findings showed that, the bulbs exhibit moderate anti-microbial and anti-inflammatory property, wound healing facilitator and a better dietary supplements to a victim of autoimmune diseases. ${ }^{14}$

Cite this article: Ayeni G, Pooe OJ, Singh M, Nundkumar N, Simelane MBC. Cytotoxic and Antioxidant Activities of Selected South African Medicinal Plants. Pharmacog J. 2019;11(6) Suppl:1532-9. 
Eucosterol,16ß-hydroxy-eucosterol and Eucosterol glycoside are the natural nortriterpenes family isolated thus far from Eucomis species. ${ }^{21,22}$

Ziziphus mucronata is a member of Rhamnaceae family, drought tolerant with ability to withstand high temperature. They are known as buffalo thorn and are evenly distributed throughout summer rainfall areas of Sub-Saharan Africa, extending from South Africa northwards to Ethiopia and Arabia. The roots and leaves of $Z$. mucronata have been reportedly used to treat wounds and bacteria infections, while the stem bark are being used to improve and beautify skin appearance. ${ }^{23}$ The outcome of the review conducted by Olajuyigbe and Afolayan, (2011), on the various phenolic constituents and antioxidants activity of the stem bark on this plant, showed that several medicinal herbs used as treatment option of various ailments, despite their inbuilt natural pharmacological efficacies that have been exploited in the traditional health care setting, are yet to be adequately subjected to empirical validation. ${ }^{24}$ A pentacyclic triterpenes compound known as Betulinic acid has been isolated from this herb. ${ }^{25}$ The pharmacological impacts of this herb called for its in vitro assessment.

Warburgia salutaris (Bertol.f) Chiov, belonging to Canellaceae family, known for their characteristic'peppery-bark, found within Southern Region of African Continent. ${ }^{26-28}$ Survey of literatures revealed that W. salutaris application in the treatment and management of some common ailments in communities with modern health care system with accessible and affordable medicine remained a common practice among the inhabitants, showing cultural and traditional acceptability as choiced herbs that can ease their physiological burden..$^{26,27}$ The stem bark in Zulu traditional health care is used to treat coughs, colds and other topical application such as sores and inflammatory disorders. ${ }^{29}$ Documented pharmacological activities on $W$. salutaris revealed significant analgesic, decongestant, antiinflammatory, antiplasmodic and sedative properties ${ }^{30}$. Various drimane sesquiterpenes compounds and Iso-Mukaadial acetate have been derived via systematic isolation..$^{29,31,32}$ Nevertheless, a closer evaluation of these three South African herbs (E. autumnalis, Z. mucronata and W. salutaris) on in vitro free radical inhibitory activity is still not adequately documented in the scientific literatures, despite the feedback on their healing effects in Zulu traditional medication. To the best of our knowledge, evaluation regarding, cytotoxic and antioxidant activities of these South African medicinal plants (E. autumnalis, Z. mucronata and W. salutaris) are still left unvalidated. This study aimed to provide for the first time in comparison, the empirical proof for the traditional usage of the plants.

\section{MATERIALS AND METHODS}

\section{Chemicals}

Chemicals and other reagents used in the cause of the experiment were all of analytical grade procured from Sigma-Aldrich Company, Limited, South Africa, unless otherwise started.

\section{Collection of plant materials}

Warburgia salutaris (stembark), Ziziphus mucronata (stem bark) and Eucomis autumnalis (bulbs) are the investigative plants materials in the current research. Fresh part of interest of these herbs were collected in the Botanical garden under the supervision of University of KwaZuluNatal, Pietermaritzburg Campus $\left(29^{\circ} 37^{\prime} 30^{\prime \prime} \mathrm{S}, 30^{\circ} 24^{\prime} 14^{\prime \prime} \mathrm{E}\right)$, South Africa. Authentication was done by Mrs Alison Young with voucher specimen numbers; NU0043932, NU0049311, NU0048862. The plants were deposited at the Herbarium Unit, Botany Department of the same Institution.

\section{Preparation of the extracts}

The dried plant parts $(1 \mathrm{~kg})$ were sequentially extracted separately with methanol $72 \mathrm{~h}$. Separation of the extracts mixture was done by the use of
Whatman No. 1 filter paper. Minimum volume of organic solvents were recovered at a decreased pressure of $40 \pm 2^{\circ} \mathrm{C}$, with the aid of Heidolph rotary evaporatory machine. Concentrated extracts were dried under the fume hood overnight. The resultants yields were estimated.

\section{Antioxidant activity}

\section{2,2-diphenyl-1-picryl hydrazyl assay}

Scavenging activity of the three plant extracts was evaluated using 2,2-diphenyl-1-picryl hydrazyl (DPPH) following a method previously described by Simelane et al. ${ }^{13}$ with minor modifications. Briefly, $2 \mathrm{~mL}$ of the methanolic extracts at concentrations range $(20-100 \mu \mathrm{g} / \mathrm{mL})$ was added to equal volume of DPPH ( $2 \mathrm{mg})$ radical solution. The combined heterogenous solution was vigorously shakened and left upon standing for 30 to $60 \mathrm{~min}$ for proper colour visualization. Calibrations of absorbance values for the resultant solution was read at a wavelength of $517 \mathrm{~nm}$.

\section{Superoxide anion $\left(\mathrm{O}_{2}^{-}\right)$assay}

Reductive and inhibitory ability of $Z$. mucronata, W. salutaris and E. autumnalis on nitroblue tetrazolium (NBT) upon exposure to riboflavin-light generated NBT complex was investigated using the stepwise outlined procedure demonstrated by Nagai et al., ${ }^{34}$. The reacting components including $0.02 \mathrm{~mL}$ of the methanolic extracts $(20-100 \mu \mathrm{g} / \mathrm{L}), 0.02 \mathrm{~mL}(50 \mathrm{mM}, \mathrm{pH} 10.5)$ of $\mathrm{NaCO}_{3}$ buffer, $0.15 \%$ bovine serum albumin, $3 \mathrm{mM}$ xanthine, $3 \mathrm{Mm}$ ethylenediaminetetraacetic acid (EDTA), $0.75 \mathrm{mM}$ NBT were mixed. The combined solution was incubated at $25{ }^{\circ} \mathrm{C}$ for $20 \mathrm{~min}$. The reaction was initiated and proceed faster on the addition of $0.02 \mathrm{~mL}$ of xanthine oxidase. Following the development of blue formazan observed for $20 \mathrm{~min}$ at $25^{\circ} \mathrm{C}$, is the stepwise introduction of $0.02 \mathrm{~mL}$ of $6 \mathrm{mM} \mathrm{CuCl}$. The absorbance values of the solvent system was calorimetrically determined at $560 \mathrm{~nm}$.

\section{Nitric oxide (NO-) inhibitory assay}

The production of nitric ion from sodium nitroprusside in water and oxygen at the physiological $\mathrm{pH}$ form the basis of this assay. Griess Illosvoy method of quantification was employed for the nitric oxide production. ${ }^{35}$ Nitric oxide neutralizers competitively inhibit oxygen affinity and limit the concentration of nitric oxide production. ${ }^{36}$ The reacting components include $3 \mathrm{~mL}$ out of the entire solution, comprising $2 \mathrm{~mL}$ of $10 \mathrm{mM}$ sodium nitroprusside, $0.5 \mathrm{~mL}$ of phosphate buffer saline $(\mathrm{pH} 7.4,0.01 \mathrm{M})$ with $0.5 \mathrm{~mL}$ of varying concentrations $(20-100 \mu \mathrm{g} / \mathrm{L})$ of the methanolic extract of $Z$. mucronata, W. salutaris and E. autumnalis, mixed and incubated for $2 \mathrm{~h} 30 \mathrm{~min}$ at room temperature. In addition to the solvent system above $(0.5 \mathrm{~mL}$ containing nitrite), $1 \mathrm{~mL}$ of sulphanilic acid system ( $0.33 \%$ in $20 \%$ glacial acid) was pipetted forming a resultant solution. The solution was left to stand for $5 \mathrm{~min}$ at room temperature to give room for normal diazotization. The reaction was completely initiated at the instant of introducing $1 \mathrm{~mL}$ of naphthylethylenediamine dihydrochloride $(0.1 \%)$ in diffused light and was allowed to remain for $30 \mathrm{~min}$. Absorbance at $540 \mathrm{~nm}$ was calibrated.

\section{Hydroxyl radical $(-\mathrm{OH})$ inhibitory assay}

The hydroxylation of benzoic acid technique stated by Chung et al., ${ }^{37}$ was employed in this bio-assay experiment. $0.2 \mathrm{~mL}$ of solution containing $10 \mathrm{mM}$ of Iron (ll) sulphate heptahydrate, Ethylenediaminetetraacetic acid and DNA, phosphate buffer ( $\mathrm{pH} 7.4$; $0.1 \mathrm{M})$ and graded concentrations $(20-100 \mu \mathrm{g} / \mathrm{L})$ of the methanolic extracts of $Z$. mucronata, $W$. salutaris and E. autumnalis were completely mixed. Addition of $200 \mu \mathrm{L}$ of hydrogen peroxide solution $(10 \mathrm{Mm})$ to the reaction system was carefully done after which the solution was incubated for $2 \mathrm{~h}$ at $37^{\circ} \mathrm{C} .1 \mathrm{~mL}$ of equal volume of TCA 
$(2.8 \%)$ and TBA $(1 \%)$ were incorporated into the mixture and heated to a boiling point in water bath for $10 \mathrm{~min}$ and were allowed to cool on ice. Calorimetric values at $520 \mathrm{~nm}$ of the solution system against the corresponding blanks were read.

\section{Reducing power assay}

The outlined procedure for evaluating the reducing ability of sample reported by $\mathrm{Oyaizu}^{38}$, was adopted in this assay. Approximately, $2.5 \mathrm{~mL}$ of the varying concentrations $(20-100 \mu \mathrm{g} / \mathrm{ml})$ of the methanolic extract of $Z$. mucronata, $W$. salutaris and E. autumnalis were respectively added to equivalent volumes of $0.2 \mathrm{M}$ phosphate buffer at $\mathrm{pH} 6.6$ and $1 \%$ potassium ferricyanide and incubated for $20 \mathrm{~min}$ at $50^{\circ} \mathrm{C} .2 .5 \mathrm{~mL}$ of $10 \%$ Trichloroacetic was added to the solution and centrifuged at 1000 $\mathrm{rpm}$ for $10 \mathrm{~min}$. Upon centrifugation, $2.5 \mathrm{~mL}$ of the upper layer of the reaction mixture was inoculated into an equal ratio of distilled water and $\mathrm{FeCl}_{3}(0.5 \mathrm{~mL}, 0.1 \%)$. Measurement of absorbance was done at a wave length of $700 \mathrm{~nm}$. The higher the absorbance value in this case the better the reductive capacity.

\section{Metal chelating activity}

The method described by Decker and Welch ${ }^{39}$ was used to evaluate the iron (II) chelating ability of the extracts. At graded concentrations (20$100 \mu \mathrm{g} / \mathrm{L}$ ) of the methanolic extracts of $Z$. mucronata, W. salutaris and E. autumnalis, $0.5 \mathrm{~mL}$ of the organic solution was added to $1.6 \mathrm{~mL}$ of purified $\mathrm{H}_{2} \mathrm{O}$ and $0.05 \mathrm{~mL}$ of iron (ll) chloride $(2 \mathrm{mM})$ respectively. Initiation of reaction was done when $5 \mathrm{mM}$ ferrozine $(0.1 \mathrm{~mL})$ was added at observation period of 30 secs. The entire reaction system was maintained at $25^{\circ} \mathrm{C}$ for $10 \mathrm{~min}$, after evenly shakened on the orbital shaker. The absorbance values were determined at a corresponding wavelength of $562 \mathrm{~nm}$.

\section{Lipid peroxidation inhibitory assay}

Inhibitory activity of the extracts against induction of peroxidative reaction by $\mathrm{Fe}^{2+} /$ Ascorbate complex was experimentally evaluated on liver obtained from Sprague-Dawley rats with average weight of 180 g. Perfusion and homogenization $(1: 10 \mathrm{w} / \mathrm{v})$ employing $120 \mathrm{mM}$ potassium chloride, $50 \mathrm{mM}$ phosphate buffer $(\mathrm{pH} 7.4)$. Centrifugation $\left(700 \times \mathrm{g}, 10 \mathrm{~min}\right.$, at $\left.4{ }^{\circ} \mathrm{C}\right)$ of the supernatant was carried out at a low temperature $\left(-20^{\circ} \mathrm{C}\right)$. Lowry et al.,,$^{40}$ methodology of protein quantification was adopted, after which the protein contents have been carefully calibrated up to a concentration of $10 \mu \mathrm{g} / \mathrm{mL}$. The composite mixture of the reactants comprising equal volume of $(0.1 \mathrm{~mL})$ of the diluted homogenate, Tris-hydrochloric acid buffer $(20 \mathrm{mM} \mathrm{pH} \mathrm{7),}$ potassium chloride $(30 \mathrm{mM})$, and including varying concentrations $(20$ - $100 \mu \mathrm{g} / \mathrm{mL}$ ) of the methanolic extracts of $Z$. mucronata, W. salutaris and $E$. autumnalis, were incubated for $5 \mathrm{~min}$ which was maintained at $37^{\circ} \mathrm{C}$. Addition $\mathrm{AA} / \mathrm{Fe}^{2+}(0.1 \mathrm{~mL} ; 0.1 \mathrm{mM})$ to the reacting system initiated peroxidative reaction after incubating at $37^{\circ} \mathrm{C}$ for $30 \mathrm{~min}$. Lipid peroxide values were determined by the thiobarbituric acid method at a wavelength of $532 \mathrm{~nm} .{ }^{41}$

\section{MTT assay procedure}

Cytotoxicity evaluation of methanolic extracts of $Z$. mucronata, $W$. salutaris and E. autumnalis, employing 3-(4,5-dimethyl thiazole2-yl)-2,5-diphenyltetrazolium bromide (MTT) was conducted on HEK293 cells (a non-cancerous cell) in 96 well micro plates reader in accordance with the method clearly outlined by Mosmann ${ }^{42}$ with some modifications. Incubation of the varying concentrations (20$100 \mu \mathrm{g} / \mathrm{mL}$ ) of the methanolic extract, following the cell line, HEK293 in an ideal experimental condition composed of $5 \% \mathrm{CO}_{2}$ at $37^{\circ} \mathrm{C}$ for an observation period of $48 \mathrm{~h}$. The existing medium was carefully separated, while the addition of the new medium $(100 \mu \mathrm{g} / \mathrm{mL})$ and $5 \mathrm{mg} / \mathrm{mL}$ of MTT solution in PBS to the various wells on the plates prior to final incubation period. The solution containing MTT were incubated alongside with cells at $37^{\circ} \mathrm{C}$ for $4 \mathrm{~h} .200 \mu \mathrm{L}$ of DMSO was introduced into the well in order to solubilize formazan salt upon the removal of both the MTT solution and the medium. Absorbance at the wavelength of $570 \mathrm{~nm}$ was calibrated by $96 \mathrm{~A}$ microplate reader. The percentage cell viability was calculated with the statistic shown below:

$$
\% \text { Cell viability }=\frac{\text { Asorbance of sample } \times 100}{\text { Absorbance of control }}
$$

\section{Assay on DNA protection}

Evaluation on the ability of Z. mucronata, W. salutaris and E. autumnalis extracts to protect a transformed variant of DNA (pET151/D-TOPO plasmid) extracted from Escherichia coli against free radicals damaging agent from Fenton's reagent composition as previously performed but with specific modifications. ${ }^{43}$ The composite reaction mixture were made up of $10 \mu \mathrm{L}$ of plasmid DNA, $2.5 \mu \mathrm{L}$ of Fenton's reagent composition $\left(\mathrm{H}_{2} \mathrm{O}_{2}(30 \%)\right.$, Ascorbic acid $(50 \mathrm{Mm})$ with $80 \mathrm{Mm}$ of iron (III) chloride] and concentration of the methanolic extracts (in methanol and DMSO separately) at $20 \mu \mathrm{g} / \mathrm{mL}$ inclusively. The total volume of the reaction mixture was diluted to $20 \mu \mathrm{L}$ with distilled water. The mixture were incubated for $30 \mathrm{~min}$ at $37^{\circ} \mathrm{C}$. Addition of 5 $\mu \mathrm{L}$ of the binding dye (bromophenol blue; $0.25 \%$ composed of $50 \%$ glycerol) were followed immediately after the incubation period. $20 \mu \mathrm{L}$ of each sample was loaded on agarose gel system $(0.8 \%)$ in $10 \times$ TAE buffer solution, stained with $5 \mu \mathrm{L}$ of ethidium bromide for brilliant visualization. Electrophoretic mobility of the agarose gel composition was carried out for $60 \mathrm{~min}$ at 90 volts. The nicked and native DNA were visualized using the G:BOX $\mathrm{F}_{3}$ Gene System image visualizing technique for proper inference.

\section{Statistical analysis}

The data were represented in mean \pm standard error of the mean of three replicates $(n=3)$. The inhibitory concentration with $50 \%$ values of inhibition $\left(\mathrm{IC}_{50}\right)$ was calculated from the graph of percentage inhibition and later subjected to Instat Software, Bonferroni multiple comparison test, Graph Pad Prism 5, Instat Software (San Diego, USA\%). Inhibition of each parameter was estimated using the following fomular:

$$
\% \text { inhibition }=[1-(\text { Sample }) /(\text { Control })] \times 100
$$

\section{RESULTS}

\section{Scavenging activity}

Ziziphus mucronata, Warburgia salutaris, and Eucomis. autumnalis were assessed for in vitro free radical neutralizing power on $\mathrm{DPPH}, \mathrm{O}^{-}$ $\mathrm{OH}, \mathrm{NO}^{-}$as depicted in Table 1 . Ascorbic acid (AA) and Butylated hydroxyltoluene (BHT) were selected as model molecules in this in vitro evaluation. Comparatively with the standard synthetic antioxidant that were employed in the assessment, the plant extracts exhibited viable inhibitory ability on the radicals (Table 1 ).

\section{DISCUSSION}

The scavenging influence of Z.mucronata on DPPH at varying concentrations range $(20-100 \mu \mathrm{g} / \mathrm{mL})$ were reasonably significant with the highest percentage level of inhibition $(84.66 \%)$ at $100 \mu \mathrm{g} / \mathrm{mL}$. The $\mathrm{IC}_{50}$ value was $12.88 \mu \mathrm{g} / \mathrm{mL}$ which was relatively lower than the synthetic antioxidant (AA with $\mathrm{IC}_{50}$ value of $3.16 \mu \mathrm{g} / \mathrm{mL}$ and $\mathrm{BHT} \mathrm{IC}_{50}$ value, $0.15 \mu \mathrm{g} / \mathrm{mL}$ ). W. salutaris also displayed reasonable level of inhibitory activity at these concentrations. The scavenging effects (93.62\%) was on an increase at the peak concentration, with IC50 value, $20.32 \mu \mathrm{g} / \mathrm{mL}$. Extract of E. autumnalis has $\mathrm{IC}_{50}$ value of $57.02 \mu \mathrm{g} / \mathrm{mL}$, with $60.12 \%$ inhibition at the highest concentration.

The inhibitory effects brought about by the scavenging activity of the crude extract could possibly due to their inherent chemical substances 
Table 1: $I C_{50}(\mu \mathrm{g} / \mathrm{mL})$ and $L C_{50}(\mu \mathrm{g} / \mathrm{mL})$ values of $Z$. mucronata, W. salutaris, E. autumnalis on different assay models [DPPH, Superoxide anion $\left(\mathrm{O}_{2}^{-}\right)$, Hydroxyl $\left({ }^{-} \mathrm{OH}\right)$, Nitric oxid ( $\left.\mathrm{NO}^{-}\right)$, Lipid peroxidation (LP) and Cytotoxicity (CYT)].

\begin{tabular}{|c|c|c|c|c|c|c|}
\hline \multicolumn{7}{|c|}{$I C_{50}(\mu \mathrm{g} / \mathrm{mL})$} \\
\hline & DPPH & $\left(\mathrm{O}_{2}^{-}\right)$ & $(-\mathrm{OH})$ & $\left(\mathrm{NO}^{-}\right)$ & LP & CYT. $\left(\mathrm{LC}_{50}\right)$ \\
\hline $\mathrm{ZIZ}$ & $12.88 \pm 0.46$ & $43.95 \pm 0.23$ & $67.45 \pm 0.28$ & $55.46 \pm 0.32$ & $41.40 \pm 1.53$ & 5902.01 \\
\hline WB & $20.32 \pm 3.7$ & $42.85 \pm 3.23$ & $81.28 \pm 0.44$ & $2.09 \pm 0.15$ & $21.78 \pm 0.72$ & 3118.89 \\
\hline EUM & $57.02 \pm 0.62$ & $75.86 \pm 0.5$ & $>100$ & $>100$ & $>100$ & 6011.74 \\
\hline A. Acid & $3.16 \pm 0.32$ & $53.2 \pm 0.9$ & $>100$ & $30.20 \pm 0.34$ & $7.26 \pm 0.54$ & 25234.81 \\
\hline BHT & $0.15 \pm 0.27$ & $71.12 \pm 0.24$ & $65.92 \pm 0.18$ & $>100$ & $13.18 \pm 0.27$ & \\
\hline
\end{tabular}

Values are mean \pm SEM $\left(\mathrm{n}=3\right.$ ) of $\mathrm{IC}_{50}$ values of Z. mucronata (ZIZ), W. salutaris (WB), E. autumnalis (EUM), Ascorbic Acid (AA) and Butylated hydroxyltoluene $(\mathrm{BHT})$, respectively.

that act as radical quencher and can freely transfer electron to the counterpart molecules during the initiation and propagatory stage of these ROS. ${ }^{33,44-47}$

Inhibitory activity of the crude form (extracts) of the plants were evaluated on the superoxide and hydroxyl anion radicals. These radicals are thought to have beneficial and damaging impact on the important biological molecules. ${ }^{9}$ The scavenging assay experiment on superoxide for the three extracts in the present study, (Table 1) revealed high level of inhibition on superoxide propagation corresponding with the $\mathrm{IC}_{50}$ values to $Z$. mucronata $(43.95 \mu \mathrm{g} / \mathrm{mL}), W$. salutaris, $(42.85 \mu \mathrm{g} / \mathrm{mL})$ and E. autumnalis $(75.86 \mu \mathrm{g} / \mathrm{mL})$ and that of the standards agents (AA and BHT) used in the comparative measurement of the extent of the inhibition on the radical oxide. Hydroxyl radical has been reported as the most active interms of reactivity among the radical species and are known with the frequent attack on the vital macro-molecular blocks. ${ }^{15}$ Z. mucronata and W. salutaris estimated $\mathrm{IC}_{50}$ values were $67.45 \mu \mathrm{g} / \mathrm{mL}$ and $81.28 \mu \mathrm{g} / \mathrm{mL}$. The $\mathrm{IC}_{50}$ values of E. autumnalis was experimentally greater than the peak concentration selected in the course of the investigation a mark of weak inhibitory action on the hydroxide radical ion. The potency of $Z$. mucronata and $W$. salutaris in view of their hydroxide radical scavenging property were in close comparison with the standard synthetic molecule interms of their ability to prevent the progression of this hydroxyl anion. It is vivid that these herbs are inherent with natural molecules that are thought to aid in limiting the propagation of free radicals anions and increase the dietary antioxidants value in vivo.

The de novo synthesis and metabolism of nitric oxide is being used to monitor and evaluate its amount in the biological system. ${ }^{48}$ The scavenging activity of the crude extracts form of $Z$. mucronata, $W$. salutaris and E. autumnalis with the standard synthetic antioxidants are presented in Table $1 . W$. salutaris exhibited potent inhibitory ability to the propagatory nature of the nitric oxide ( IC $_{50}$ value of $2.09 \mu \mathrm{g} / \mathrm{mL}$ ) better than the extracts of $Z$. mucronata and E. autumnalis and the standard antioxidant employed combined in this study. The scavenging power of $Z$. mucronata was moderately lower $\left(\mathrm{IC}_{50}\right.$ value of $55.46 \mu \mathrm{g} /$ $\mathrm{mL})$ relative to AA $(30.20 \mu \mathrm{g} / \mathrm{mL})$ and BHT with no inhibitory activity on the nitric oxide under the condition of this investigation, and as such similar in action to E. autumnalis. Evaluation at the level of both in vivo and in vitro nitric ion is vital to the cellular activities. ${ }^{49,50}$. Thus, it is however worthy to postulate in clear terms that, $W$. salutaris is the strongest scavenger of free radical of all the extracts in this assessment including the synthetic antioxidant molecules. At any rate, the extracts significantly prevent the dominant and propagation of nitric ion at different capacity. In the overall, the inhibitory influence of $W$. salutaris, $Z$. mucronata and E. autumnalis might probably attributed to the presence of bioactive molecules reside in the plant extracts and are the main factors eliciting these pharmacological phenomenal.

\section{Lipid peroxidation assay}

Plant extract have been reported to exert inhibitory action on $\mathrm{Fe}^{2+}$ induced lipid peroxidation in tissues homogenates in vitro and ex- vivo with a significant reduction in malondialdehyde (MDA) contents owing to inbuilt antioxidant properties exerted by phenolic moiety, with the ability to scavenge DPPH radical and potent reductive ability on any radical assay experiment. ${ }^{47,51,52}$ The plant's extract in their crude states have demonstrated variously, anti-lipid peroxidative ability by different modes (Table 1). Z. mucronata and W. salutaris exihibited $64.824 \%, 77.286 \%$ inhibition at the highest concentration $(100 \mu \mathrm{g} / \mathrm{mL})$. E. autumnalis, has no degree of antiperoxidative action in this assay at the vary concentration $(20-100 \mu \mathrm{g} / \mathrm{mL})$ under the condition of our investigation. The $\mathrm{IC}_{50}$ values of $Z$. mucronata and $W$. salutaris were experimentally estimated at $41.40 \mu \mathrm{g} / \mathrm{mL}$ and $21.78 \mu \mathrm{g} / \mathrm{mL}$. While the synthetic antioxidants; AA and BHT with $\mathrm{IC}_{50}$ values of $7.261 \mu \mathrm{g} / \mathrm{mL}$ and $13.183 \mu \mathrm{g} / \mathrm{mL}$ repectively, at same concentration. The anti-lipid peroxidative activity shown so far by $Z$. mucronata and $W$. salutaris in their crude states have placed these medicinal plants the more as important promising agents that could prevent cellular oxidation of the bio-membrane.

\section{Reducing power}

Reducing capacity of any molecule be it natural or synthetic is no doubt depends on the nature of the molecule and the inherent property to prevent free radical propagation through the transferring of proton to the radical species ${ }^{53}$ and inhibition of the occurrence of lipid peroxidative phenomenon via certain flavonoids or phenolics constituents. ${ }^{47}$ Considering the results presented in Figure $1 \mathrm{~A}$, the percentages reductive capacity of $Z$. mucronata, $W$. salutaris and $E$. autumnalis were given as $71.76 \%, 76.69 \%$ and $61.11 \%$ respectively, at the maximum concentration $(100 \mu \mathrm{g} / \mathrm{mL})$ compared to the synthetic antioxidants molucules used for the assessement in this assay, BHT (65.61\%) and AA (51.67\%) at same concentration $(20-100 \mu \mathrm{g} / \mathrm{mL})$ Hence, reducing action exerted by crude extracts in this comparative study relative to the standard agents employed is a confirmation that natural products has inbuilt capacity to limit oxidation of biomolucule. ${ }^{53}$

\section{Metal chelating activity}

It has been report in the literatures that most natural occurring antioxidant are good chelators of ferrous ions but mostly demonstrate weak hydroxyl radicals scavenging activity in most experimental studies. ${ }^{54}$ The binding affinity of ferrous ion and free radicals neutralizing activity of a reduced molecules is a reliable marker of metal chelating property. ${ }^{55}$ There was moderate to high chelating activity observed from the crude extracts investigated in this assay. $Z$. mucronata chelated upto $77.30 \%$, compared with EDTA (82.07\%) and CA (64.17\%) at the concentration of $100 \mu \mathrm{g} / \mathrm{mL}$ (Figure 1B). There was minimum chelating effects observed in the manner in which both $W$. salutaris $(68.867 \%)$ and E. autumnalis (64.836\%) at same concentration compared to the investigative standard employed. The results is in complete agreement with the observation earlier cited in the literary study that antioxidant mechanisms are synergistic and complementary in action. ${ }^{55}$ 


\section{Cytotoxicity}

Sigidi et al., ${ }^{56}$, earlier postulated that in order for any natural product of herbal origin to be clinically relevance, there must be preferencial lithality that is aiming at the host system in question, and hence interference with metabolic activities with bearable level of lethality. Cytotoxicity evaluation of methanolic extracts of $Z$. mucronata, $W$. salutaris and $E$. autumnalis, using MTT assay procedure on HEK293 cell line and the experimental control counterpart employed, ascorbic acid respectively are represented in Table 1. Evaluation of percentage lethality of these extracts on HEK293 cells resulted to low toxic concentration. Lethal concentration of these extracts at the peak varying concentration were estimated as $5902.01 \mu \mathrm{g} / \mathrm{mL}, 3118.89 \mu \mathrm{g} / \mathrm{mL}$ and $6011.74 \mu \mathrm{g} / \mathrm{mL}$ for $Z$. mucronata, W. salutaris and E. autumnalis respectively. The low level of cytotoxicity could probably not associated with any deliterous effects on the cell survival. The degree of toxicity exhibited by these extracts are some way related to the level of preference of these extracts on the cell line employed. ${ }^{56}$ It is therefore, imperative to note that the experimental herbs have wide range of safety marging of toxicity, with minimal amount of lethal compounds, but when cautiously administered, they are therapeutically viable.

\section{DNA protection against oxidative stressing agent}

In this study we have been able to establish for the first time on these plants, the significant correlation between protective ability of DNA and that of the free radical $(-\mathrm{OH})$ scavenging strength of the methanolic extracts form of Z. mucronata, W. salutaris and E. autumnalis (Figures 2). The results of the in vitro assay under this assessment tally in many ways with the DNA protective ability against hydroxyl radical intoxication in an extract dependent phenomenon. At dose of $20 \mu \mathrm{g} / \mathrm{mL}, W$. salutaris exhibited better protective power slightly higher than $Z$. mucronata and farther much higher than E. autumnalis as against the digested DNA with restriction enzyme (BamH1) and normal-undigested DNA. The conferment of protection on DNA against any damaging agent is an indicator of repairement and restoration from the nicked conformation (linear) of the DNA from pET151/D-TOPO variant to circular form (native form).This observation, has open up a new area of application in

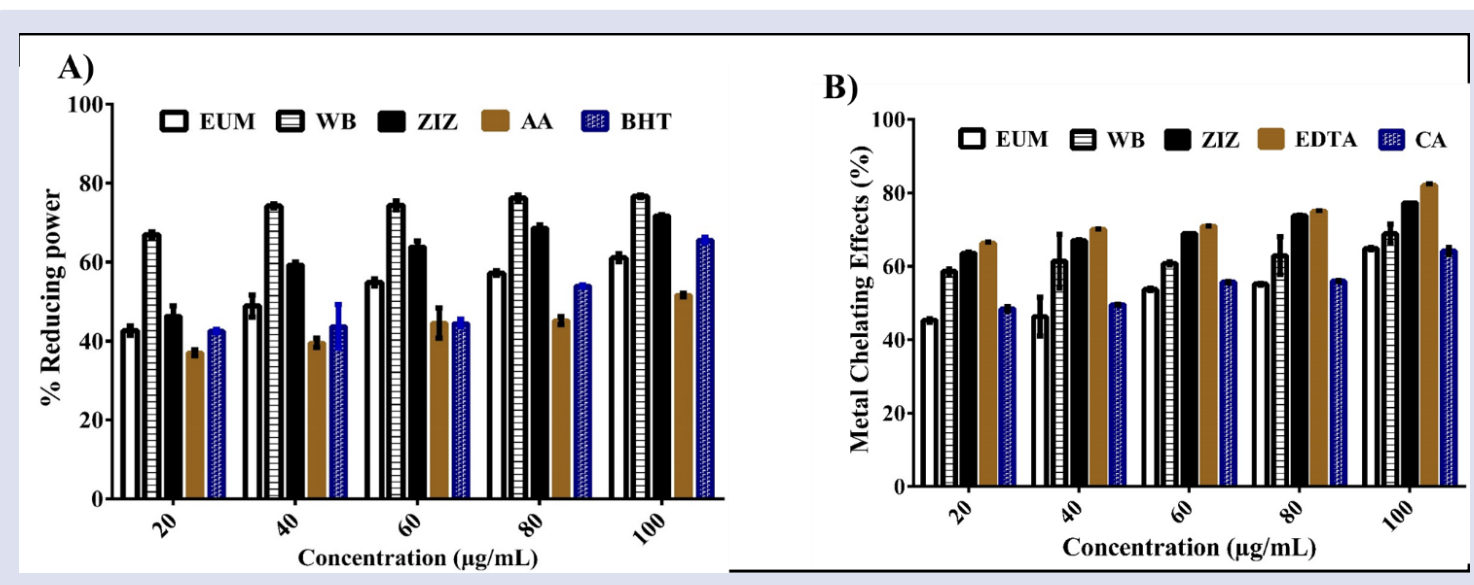

Figure 1: Protective reducing power (A) and metal chelating ability (B) each of the Z. mucronata (ZIZ), W. salutaris (WB), E.autumnalis (EUM).

Assays controls are represented by Butylated Hydroxytoluene (BHT), Ascorbic Acid (AA), Citric Acid (CA) and Ethylenediaminetetraacetic Acid (EDTA). Values are mean $\pm \operatorname{SEM}(n=3)$.

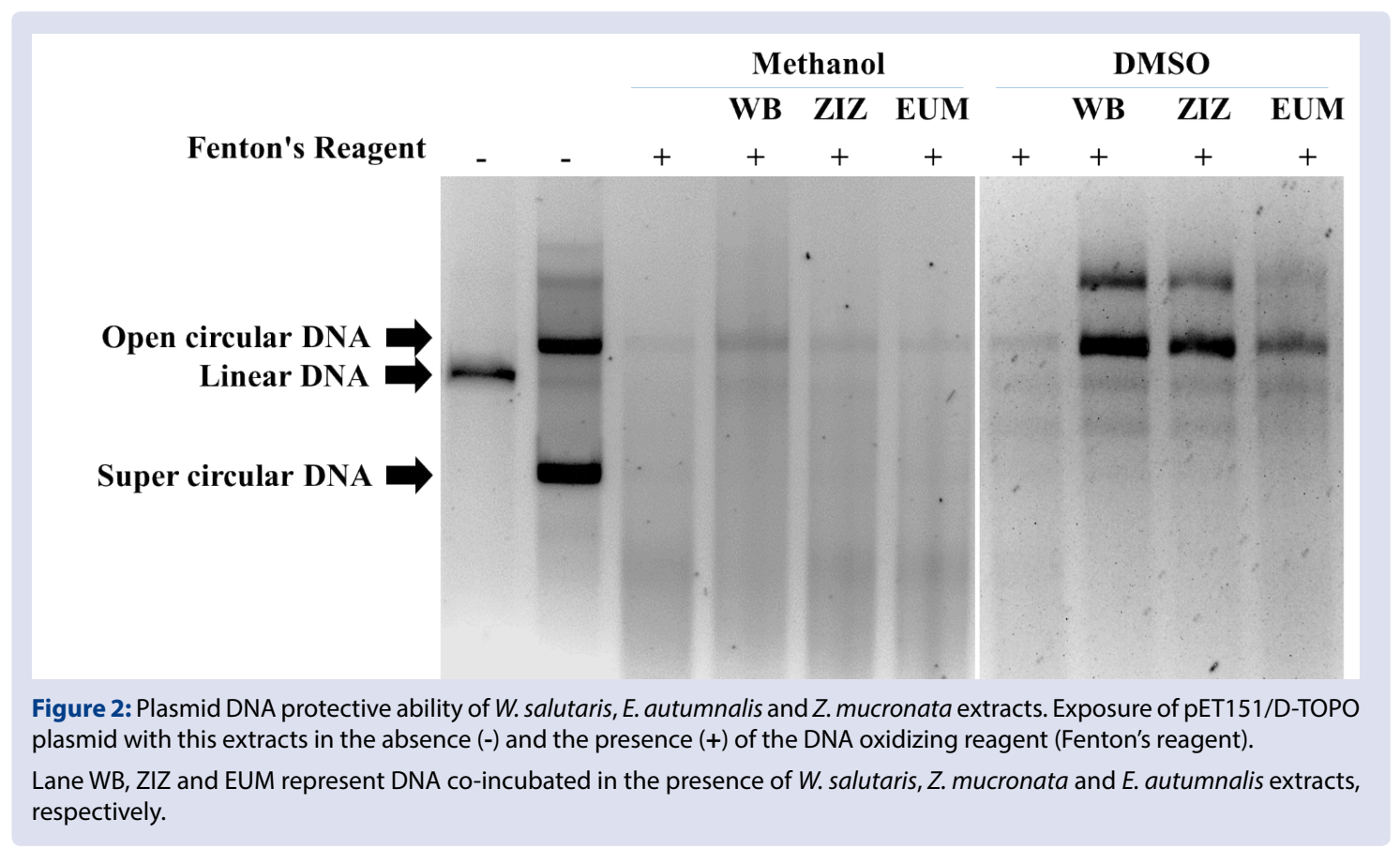


biomedical science in the arena of using DNA protection as a yardstick in the evaluation of antioxidant status of medicinal plants and vice versa. In the past, Golla and Bhimathati reported that Desmostachya bipinnata L. Stapf extract at $50 \mu \mathrm{g} / \mathrm{mL}$ scavenged and blocked oxidative damaging effects of hydrogen peroxide from Fenton's reagent and reduced iron (III) component of the stressing agent imposed on DNA. ${ }^{57}$

The impact of the hydroxyl radical agent on the plasmid DNA is thought to be through induction of oxidative fracture on the GuanineCytosine base pair in the DNA strands to a different conformation with no biological significance (linear or inactive form). Interaction of linear form of DNA with hydroxyl radical in the reaction compartment progressively advances to fracture strands. The nitrogenous components of the DNA are oxidatively attacked by the hydroxyl anion with strong affinity and create in the nucleotide radical ions (base anion and sugar anion containing negatively charged phosphate bond). Thus, charged base radical anion combined with sugar counterpart resulting in an unstable complememtary structure of the nucleotide molecule to separate..$^{58}$ Evidence abound from the data generated in the ongoing work that $Z$. mucronata, $W$. salutaris and $E$. autumnalis competently effective in protecting by limiting radical anion evolved from Fenton's reaction. Nevertheless, the intensity and appearance of the damaged DNA diminizes from E. autumnalis, $Z$. mucronata and $W$. salutaris. The protective nature of these extracts on DNA against free radical oxidative breakage is synonymous to the availability of primary metabolites of the family of polyphenolics and flavonoids known for neutralizing, stabilizing and limiting free radical molecules in vitro and in vivo. ${ }^{13,57,59}$

Interestingly, organic solvents exhibit various preferences inorder to enhance protection to DNA against oxidizing agent and prevent DNA nicking effects. Organic liquid are known to avert direct interaction of the charged components of DNA with the iron (II) ion and hydroxyl anion from Fenton's reagents. DMSO has been described to have strong affinity in scavenging radical ion in the previous DNA nicked protection assay ${ }^{60}$ It is probable that the DMSO solubilized extracts completely chelate iron (II) and neutralize hydroxyl radical ion released by Fenton's reagent readily and better of than that methanol solvated extracts.

Thus, the demonstration by Z. mucronata, W. salutaris and E. autumnalis specifically, regarding the shielding capacity of DNA molecules from toxic chemicals, is a pointer to the fact that they are tested candidates in the treatment of oxidative associated diseases and promising agents in the treatment of molecular and genetic diseases.

\section{CONCLUSION}

Z. mucronata, W. salutaris and E. autumnalis are indigenous medicinal plants domiciled in South Africa. They have demonstrated potent scavenging index in vitro and have even demonstrated competent shielding of DNA in the face of oxidative initiating and damaging molecule, DNA protection was concluded to be plant extract specific and potentially phyto-dependent. Nonetheless, reliably, these herbs showed potent activities against free radical propagation and as such could as well serve as alternative therapy in the biomedical world and promising agent in the therapeutic approach in the treatment of free radical associated diseases. To this end, the present study has justified the continuous participation of indigenous herbs as a complementary agent in treatment regimen. Hence, assessment of these plants and their derivatives in in vivo model experiment is worthy of investigation.

\section{COMPETING INTEREST}

All Authors declare that no form of conflicting interest in this study.

\section{ACKNOWLEDGEMENTS}

We would like to appreciate the support received from the Research Funding Body, at the University of KwaZulu-Natal (UKZN) and South
Africa National Research Foundation for the timely release of the funds to purchase all the chemicals and reagents needed for this work.

\section{REFERENCES}

1. Haidan Yuan QM, Li Ye, Guangchun Piao. The traditional medicine and modern medicine from natural products. Molecules. 2016;21(559):1-18.

2. Hassan SW, Salawu K, Ladan MJ, Hassan LG, Umar RA, Fatihu MY Hepatoprotective, antioxidant and phytochemical properties of leaf extracts of Newbouldia laevies. Int J PharmTech Res. 2010;2(1):573-84

3. Xie S, Zhou J. Harnessing plant biodiversity for the discovery of novel anticancer drugs targeting microtubules. Front Plant Sci. 2017;8:720.

4. Elgazar AA, Selim NM, Abdel-Hamid NM, El-Magd MA, El Hefnawy HM. Isolates from Alpinia officinarum Hance attenuate LPS-induced inflammation in HepG2 Evidence from in silico and in vitro studies. Phyther Res. 2018;32(7):1273-88.

5. Devasagayam TPA, Tilak J, Boloor KK, Sane KS, Ghaskadbi SS, Lele RD. Free radicals and antioxidants in human health: current status and future prospects. J Assoc Physicians India. 2004;52:794-804.

6. Rinaldi M, Micali A, Marini H, Adamo EB, Puzzolo D, Pisani A, et al. Cadmium organ toxicity and therapeutic approaches: a review on brain, kidney and testis damage. Curr Med Chem. 2017;24(35):3879-93.

7. Finkel T, Holbrook NJ. Oxidants, oxidative stress and the biology of ageing Nature. 2000;408:239-47.

8. Harman D. Aging: a theory based on free radical and radiation chemistry. $J$ Gerontol. 1956;11:298-300

9. Sies H. Biochemistry of oxidative stress. Chem Intern Ed Eng. 1986;25:105871.

10. Gutteridge JMC, Halliwell B. The measurement and mechanism of lipid peroxidation in biological systems. Trends Biochem Sci. 1990;15(4):129-35.

11. Gul MZ, Bhakshu LM, Ahmad F, Kondapi AK, Qureshi IA, Ghazi IA. Evaluation of Abelmoschus moschatus extracts for antioxidant, free radical scavenging, antimicrobial and antiproliferative activities using in vitro assays. BMC Complement Altern Med. 2011;11(1):64

12. Hassan SW, Ayeni G, Wasagu RSU, Umar RA, Agaie BM, Farouk UZ. Research paper hepatoprotective effect of leaf extracts of newbouldia laevis on carbontetrachloride- intoxicated rates. J Glob Biosci. 2015;4(5):2258-81.

13. Simelane MBC, Lawal OA, Djarova TG, Opoku AR. In vitro antioxidant and cytotoxic activity of Gunnera perpensa L. (Gunneraceae) from South Africa. J Med Plants Res. 2010;4(21):2181-8.

14. Muleya E, Ahmed AS, Sipamla AM, Mtunzi FM, Mutatu W. Evaluation of anti-microbial, anti-inflammatory and anti-oxidative properties Artemisia afra Gunnera perpensa and Eucomis autumnalis. J Nutr Food Sci. 2014;4(6):1-6.

15. Pavithra K, Vadivukkarasi S. Evaluation of free radical scavenging activity of various extracts of leaves from Kedrostis foetidissima (Jacq.) Cogn. Food Sci Hum Wellness. 2015;4(1):42-6.

16. Farombi EO. Mechanisms for The hepatoprotective action of kolaviron: Studies on hepatic enzymes, microsomal lipids and lipid peroxidation in carbontetrachloride-treated rat. Pharmacol Res. 2000;42(1).

17. Singh $H$, Prakash A, Kalia AN, Bakar A, Majeed A. Journal of Traditional and Complementary Medicine Synergistic hepatoprotective potential of ethanolic extract of Solanum xanthocarpum and Juniperus communis against paracetamol and azithromycin induced liver injury in rats. J Tradit Chinese Med Sci. 2016;6(4):370-6

18. Verma S, Singh SP. Current and future status of herbal medicines. Vet World 2008.

19. Pacific Bulb S. Pacific Bulb Society. In: Species Eucomis. 2017.

20. Iwalewa EO, McGaw LJ, Naidoo V, Eloff JN. Inflammation: the foundation of diseases and disorders. A review of phytomedicines of South African origin used to treat pain and inflammatory condition. African J Biotechnol A Rev. 2007;6(25):2868-85.

21. Ziegler Ren, Christoph Tamm Isolation and structure of eucosterol and 16P-Hydroxy- eucosterol, Two Novel Spirocyclic Nortriterpenes, and of a New 24-Nor-5a-chola-S, 16-diene-23-oic acid from bulbs of several eucomis species. Helv Chim Acta. 1976;59(208):6.

22. Michelangelo P, Rosa L, Vincenzo D, Matteo Adinolfi LM. Glycosides from Muscari comosum, Eucosterol glycoside and structure of its methanolysis products'. Can J Chem. 1981;59(15):2261-5.

23. Palmer E, Pitman N. Trees of southern: Covering all known indigenous species in the Republic of South Africa, South-West Africa, Botswana, Lesotho \& Swaziland. In: ; 1972:226-46.

24. Olajuyigbe OO, Afolayan AJ. Phenolic content and antioxidant property of the bark extracts of Ziziphus mucronata Willd subsp . mucronata Willd. 2011;11:130

25. Yi J, Obminska-Mrukowicz B, Yuan L, Yuan1 H. Science Immunomodulatory effects of betulinic acid from the bark of white birch on mice. J Vet Sci. 2010;11(4):305-13. 
26. Botha J, Witkowski ETF, Shackleton CM. The impact of commercial harvesting on Warburgia salutaris ('pepper-bark tree') in Mpumalanga, South Africa. Biodivers Conserv. 2004;13:1675-98.

27. Maroyi A. Warburgia salutaris (Bertol . f .) Chiov.: A multi-use ethnomedicinal plant species. 2013;7(2):53-60.

28. Marshall N. Searching for a cure: Conservation of Medicinal Wildlife Resources in East and South Africa. TRAFFIC International, Cambridge. 1998;112.

29. Rabe, $T$ and van Staden J. Isolation of an antibacterial sesquiterpenoid from Warburgia salutaris. J Ethnopharmacol. 2000;73(1-2):171-4.

30. Hutchings A, van Staden J. Plants used for stress-related ailments in traditional Zulu, Xhosa and Sotho medicine. J Ethnopharmacol. 1994;43(2):89-124.

31. Frum $Y$, Viljoen AM, Drewes SE. In vitro 5-lipoxygenase and anti-oxidant activities of Warburgia salutaris and drimane sesquiterpenoids. South African J Bot. 2005;71:447-9

32. Nyaba ZN, Murambiwa P, Opoku AR, Mukaratirwa S, Shode FO, Simelane $\mathrm{MBC}$. Isolation, characterization, and biological evaluation of a potent antimalarial drimane sesquiterpene from Warburgia salutaris stem bark. Malar J. 2018;17(1):296.

33. Brand-Williams W, Cuvelier ME, Berset CL. Use of a free radical method to evaluate antioxidant activity. Food Sci Technol-LEB. 1995;28 (1):25-30.

34. Nagai $T$, Sakai $M$, Inoue $H$, Suzuki N. Antioxidative activities of some commercially honeys, royal jelly, and propolis - ScienceDirect. Food Chem, $2001 ; 75: 237-24$.

35. Garrat DC. The qualitative analysis of drugs, 3. Japan; Chapman and Hall, 1964;456-8.

36. Badami S, Rai SR, Suresh B. Antioxidant activity of Aporosa lindleyana root. J Ethnopharmacol. 2005;101(1-3):180-4.

37. Chung S, Osawa T, Kawakishi S. Hydroxyl radical-scavenging effects of spices and scavengers from brown mustard (Brassica nigra) hydroxyl radicalscavenging effects of spices and scavengers from brown mustard. Biosci Biotechnol Biochem. 1997;16:118-23.

38. Oyaizu M. Studies on products of browning reaction antioxidative activities of products of browning reaction prepared from glucosamine- Buy PDF. Japanese J Nutr. 1986;44(6):307-16.

39. Decker EA, Welch B. Role of ferritin as a lipid oxidation catalyst in muscle food. J Agric Food Chem. 1990;38(3):674-7.

40. Lowry OH, Rosebrough NJ, Farr AL, Randall RJ. Protein measurement with folin phenol reagent. J Biol Chem. 1951;193:265-75.

41. Ohkowa M, Ohisi N, Yagi K. Assay for lipid peroxides in animal tissues by thiobarbituric acid reaction. Anal Biochem. 1979;95(2):351-8.

42. Mosmann T. Rapid colorimetric assay for cellular growth and survival: application to proliferation and cytotoxicity assays. J Immunol Methods. 1983;65(1-2):5563.

\section{GRAPHICAL ABSTRACT}

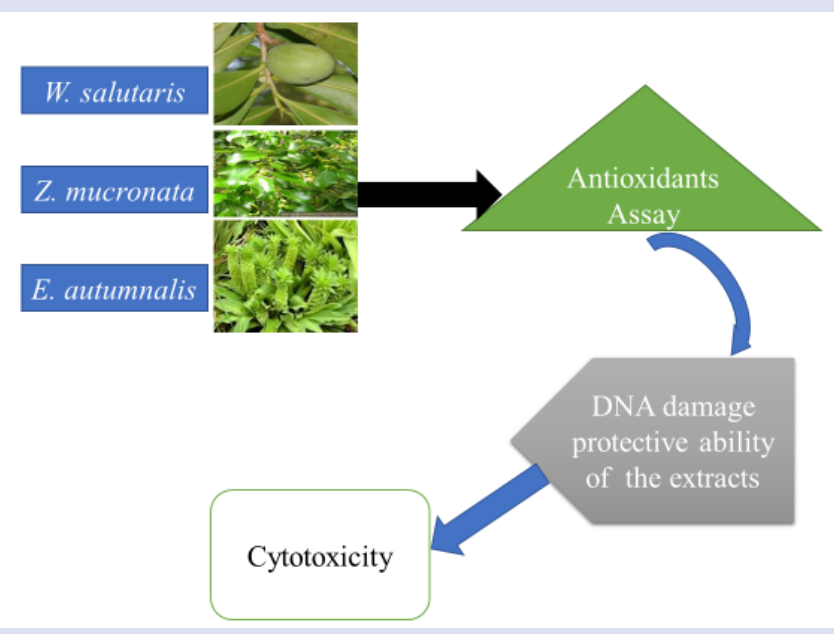

43. Lee JC, Kim HR, Kim J, Jang YS. Antioxidant property of an ethanol extract of the stem of Opuntia ficus-indica var. saboten. J Agric Food Chem. 2002:50(22):6490-6.

44. Cadenas E, Packer L. Handbook of Antioxidants. 2002;3-704.

45. Halliwell B. Dietary polyphenols: Good, bad, or indifferent for your health? Cardiovasc Res. 2007;73:341-7.

46. Kagan VE, Kisin ER, Kawai K, Serinkan BF, Osipov AN, Serbinova EA, et al Toward mechanism-based antioxidant interventions_ lessons from natural antioxidants. Ann NY Acad Sci. 2002;959:188-98.

47. Rathee JS, Hassarajani SA. Chattopadhyay S. Antioxidant activity of Nyctanthes arbor-tristis leaf extract. Food Chem. 2007;103:1350-7.

48. DTsikas. Methods of quantitative analysis of the nitric oxide metabolites nitrite and nitrate in human biological fluids. Free Radic Res. 2005;39(8):797-815.

49. Palmer RMJ; Ferrige AG; Moncada S. Nitric oxide release accounts for the biological activity of endothelium-derived relaxing factor. Nature. 1987;11 17(327(6122)):524-6

50. Halliwell B. Free radical biology \& medicine the wanderings of a free radical. Free Radic Biol Med. 2009;46(5):531-42

51. Ogunmefun OT, Fasola TR, Saba AB, Akinyemi AJ. Inhibitory effect of phragmanthera incana (schum.) harvested from cocoa (theobroma cacao) and kolanut (cola nitida) trees on fe(2+) induced lipid oxidative stress in some rat tissues - In Vitro. Int J Biomed Sci. 2015;11(1):16-22.

52. Britton RS, Leicester KL, Bacon BR. Iron toxicity and chelation therapy. Int Hematol. 2002;76(3):219-28.

53. Duh P. Antioxidant activity of burdock (Arctium lappa Linné ): Its scavenging effect on free-radical and active oxygen. Am Oil Chem. 1998;75(4):455-61.

54. Mau JL, Chao GR, Wu KT. Antioxidant properties of methanolic extracts from several ear mushrooms. J Agric Food Chem. 2001;49(11):5461-7.

55. Zhao G, Xiang Z, Ye T, Yuan Y, Guo Z. Antioxidant activities of Salvia miltiorrhiza and Panax notoginseng - ScienceDirect. Food Chem. 2006;99:767-74.

56. Sigidi MT, Anokwuru CP, Zininga T, Tshisikhawe MP, Shonhai A, Ramaite IDI, et al. Comparative in vitro cytotoxic, anti-inflammatory and anti-microbiological activities of two indigenous Venda medicinal plants. Trans| Med Commun. 2016;1(1):9.

57. Golla U, Bhimathati SSR. Evaluation of antioxidant and DNA damage protection activity of the hydroalcoholic extract of Desmostachya bipinnata L. Stapf. Sc World J. 2014;2014.

58. von Sonntag C. The chemical basis of radiation biology. Nature 1988;331(6152):128

59. Jun T, Liancai Z, Bochu W. Effects of quercetin on DNA damage induced by copper ion. Int J Pharmacol. 2007;3(1):19-26.

60. Leba LJ, Brunschwig C, Saout M, Martial K, Vulcain E, Bereau D, et al. Optimization of a DNA nicking assay to evaluate Oenocarpus bataua and Camellia sinensis antioxidant capacity. Int J Mol Sci. 2014;15(10):18023-W39.

\section{SUMMARY}

The study elucidated that extracts of $Z$. mucronata, $W$ salutaris and $E$. autumnalis plants can potentially arest free radical molecules through scavenging mechanism to prevent oxidative diseases. 


\section{ABOUT AUTHORS}

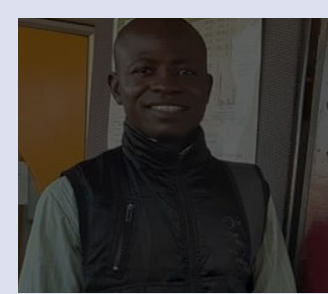

\section{Ayeni Gideon}

Mr. Ayeni research area is in the medicinal value of indigenous plants. He is currently interested in the isolation and characterization of active compounds that may be explore in the development of new drugs for liver diseases and other free radical related diseases. He is currently a staff member of Kogi State University, Anyigba, Nigeria.

Cite this article: Ayeni G, Pooe OJ, Singh M, Nundkumar N, Simelane MBC. Cytotoxic and Antioxidant Activities of Selected South African Medicinal Plants. Pharmacog J. 2019;11(6)Suppl:1532-9. 